\title{
Poverty Assessment in Rural Area of Jodhpur District in Western Arid Region of Rajasthan
}

\author{
Satya Prakash Sharma
}

Gurukul Institute of Commerce and Advance Courses, Jodhpur, India

\begin{abstract}
An attempt has been made to assess the poverty status in rural area of Jodhpur district of western Rajasthan. Two villages were randomly selected fall in the radius of $20 \mathrm{~km}$ from the Jodhpur city whereas another two villages were selected $60 \mathrm{~km}$ far from Jodhpur city with poor infrastructure facility and poor non-farm employment. 30 respondents were randomly selected from each selected village. A total of 120 respondents were selected from four village for the study. Simple tabulation method was used. For determining the poverty status, income method was used. From the study, it is revealed that agriculture, livestock, non-farm-labor activities are the main factor for poverty assessment. Size of land holding is a crucial factor. Marginal and small land holding couple with low income, are the main reason for poverty. The percentage of earners in the family size groups and percentage of dependents is inversely proportionate.
\end{abstract}

Keywords - Poverty, Rural Area, Rajasthan.

\section{INTRODUCTION}

Poverty is very complex and complicated problem and faced by various developing and under-developing countries. A simple meaning of poverty is the inability to secure minimum requirement for life, health and efficiency. These requirements include minimum human needs in respect of food, clothing, housing, education and health. The planners have been using a term 'Poverty line'. Those who can fulfill their minimum needs are 'above poverty' line and those who cannot are 'below poverty line (BPL). In1987-88, 30\% population was below poverty line; therefore large number of people in our region, particularly in the rural area is extremely poor as compared to the urban inhabitants. Poverty affects the general health and efficiencies of the people and resulted into low productivity. This inadequate economic development causes more poverty and it continues, ultimately forms the vicious civil. Problems of poverty, hunger, malnutrition, illiteracy, unemployment and poor medical facilities are enhancing the economic inequality. It means vast disparities in the income of different sections of people and it's also mean different levels of standard of living in rural as well as in urban areas. There are several definitions of poverty, and scholars disagree as to which definition is appropriate for India. Inside India, both income-based poverty definition and consumption-based poverty statistics are in use. Outside India, the World Bank and institutions of the United Nations use a broader definition to compare poverty among nations, including India, based on purchasing power parity (PPP), as well as nominal relative basis. Each state in India has its own poverty threshold to determine how many people are below its poverty line and to reflect regional economic conditions. These differences in definition yield a complex and conflicting picture about poverty in India, both internally and when compared to other developing countries of the world.

There is a wide difference exists in estimate of poverty because of the differences in methodologies, data adjustments and pre-deflation used. Studies on poverty in India began with Dadadhai Naoraoji in the $19^{\text {th }}$ Century (Naoroji 1962). The major work on poverty estimates during the pre-independence period is that of V.K.R.V. Rao (1936) who revised Naoroji estimates of per capita income. Mukherjee (1969) updated the poverty estimate of Naoroji and Rao at 1948-49 prices than laying the foundation of further work on this subject in independent India. Further, in-depth studies on poverty in independent India are by Charan Singh (1964) and Tirlok Singh (1969 ab.). After the publicaton of Myrdal's Asian Drama in 1969 when stalwarts like Dandekar and Rath (1971) and Dandekar (1980) took up the burden of the theme.

It is an accepted fact that there are large disparities both in the income and assets distribution. All over the country there is glaring evidence of concentration of wealth Considerable interest had been shown in equalities in India. Besides the government and other research bodies such as Reserve Bank of India, The National Council of Applied Economic Research. National Sample Survey organization and several scholars Bapana (1975); Bapana and Shah (1973), Phukan Umanuda (1975), Bhattacharya Pranab 
(1979) and Varghese (1987) have made significant contribution in this regard.

\section{METHODOLOGY AND SAMPLE DESIGN}

A two stage stratified sampling procedure is adopted to select the sample households. The sample included adequate proportion of social class and their working status to ensure comparison for ascertaining the effects of inequality and poverty. Sample selection is done in two stages; stage one refers to selection of villages and urban blocks of Jodhpur city and households were selected in stage two.

Two villages were selected fall in the radius of $20 \mathrm{~km}$ from the Jodhpur city whereas another two villages were selected $60 \mathrm{~km}$ far from Jodhpur city with poor infrastructure facility and poor non-farm employment. 30 respondents were randomly selected from each selected village. A total of 120 respondents were selected from four village for the study.

\section{TOOLS AND TECHNIQUE}

Income method was used to find out the poverty status of selected respondents. Income from different sources were collected.The data for the study was collected using a wellstructured exhaustive schedule through personal interview of adult male/female covering all the aspect of the study. Simple tabulation method was used. The selected respondents were categories in four different groups as follows and same are presented in the Table 1.
Category I: Income from farming comprises agriculture, livestock and allied activities (farming).
Category II: Income from agricultural ans non- agricultural labourers, collies, hand-card puller, horse/bullock cart driver, vendor, hawker, masonry etc. The wages included cash and kind(Wage earners).

Category III: Income from occupations consists of, paltry/tea shop, owner, artisans, black smith, gold smith, carpenter, tailoretc (Business and crafts).

Category IV: Income includes occupation, college, school/university teacher etc in government and private official, who get regular services from public or private institutions.

Table.1: Distribution of sample household according the main occupation of income

\begin{tabular}{|l|c|}
\hline Occupation & Rural \\
\hline Category-I & $41(34.2)$ \\
\hline Category-II & $31(25.8)$ \\
\hline Category-III & $29(24.2)$ \\
\hline Category-IV & $19(15.8)$ \\
\hline Total & $120(100.00)$ \\
\hline
\end{tabular}

Note: Figures in percentages are percentages

From the table 1, it is observed that maximum respondents belongs to first category followed by second, third and fourth.

\section{RESULTS AND DISCUSSION}

The results based on income method for determining the poverty status of rural population in Jodhpur district of western arid region of Rajasthan. The income of rural sample household from different sources are shown in the Table 2. From the table 2 , it is revealed that agriculture is the main source of household income (75\%) followed by livestock, non-farm-labor activities, business and craft. Similarly, income from agriculture accounts maximum (31.96\%) followed by business and craft, non-farm-labour, salary and livestock.

Table.2: Composition of income of the rural sample household

\begin{tabular}{|l|c|c|c|}
\hline \multicolumn{1}{|c|}{ Income Source } & $\begin{array}{c}\text { Percentage of household } \\
\text { having income source }\end{array}$ & $\begin{array}{c}\text { Income (Rs.) } \\
\text { household }\end{array}$ & Percentage of total income \\
\hline Agriculture & 75.00 & 19751 & 31.96 \\
\hline Livestock & 59.62 & 5,424 & 8.78 \\
\hline Farm-labour & 29.17 & 2,836 & 4.59 \\
\hline Non Farm-labour & 38.33 & 9,798 & 15.85 \\
\hline Business and craft & 35.83 & 14,028 & 22.70 \\
\hline Salaries & 24.17 & 8,708 & 14.09 \\
\hline Other & 14.17 & 1,256 & 2.03 \\
\hline Total & & 61,801 & 100.00 \\
\hline
\end{tabular}


Distribution of rural sample household according to operational land holding and share of income from different sources was estimated and same are shown in Table 3. From the table 3 , it is observed that land less respondent earning from non-agricultural activities contributed nearly 97 per
cent.As the size of holding increases, the income from agriculture and allied activities increases except the medium farmers (4 to 7.5 ha) who received less income from agricultural and allied activities and also from non-farmlabour.

Table.3: Household income by size of operational holding

\begin{tabular}{|c|c|c|c|c|c|}
\hline \multirow{2}{*}{$\begin{array}{l}\text { Holding group } \\
\text { (Hectares) }\end{array}$} & \multirow{2}{*}{$\begin{array}{l}\text { Percentage of } \\
\text { household to } \\
\text { total household }\end{array}$} & \multirow{2}{*}{$\begin{array}{c}\text { Percentage } \\
\text { share of income }\end{array}$} & \multicolumn{3}{|c|}{ Average/Household } \\
\hline & & & $\begin{array}{c}\text { Agricultural } \\
\text { \& Allied } \\
\text { activities }\end{array}$ & $\begin{array}{c}\text { Non- } \\
\text { Agricultural } \\
\text { activities }\end{array}$ & Total \\
\hline Land less & 20.83 & 16.16 & 1264 & 46784 & 48048 \\
\hline$<1.00$ & 9.17 & 6.32 & 8305 & 34417 & 42722 \\
\hline $1.00-2.00$ & 5.83 & 5.08 & 8766 & 45186 & 53952 \\
\hline $2.00-3.00$ & 7.50 & 6.57 & 12411 & 41850 & 52261 \\
\hline $3.00-4.00$ & 12.50 & 15.06 & 34450 & 40121 & 74571 \\
\hline $4.00-5.00$ & 15.84 & 11.74 & 22958 & 22950 & 45908 \\
\hline $5.00-7.50$ & 10.00 & 7.89 & 16271 & 32604 & 48875 \\
\hline $7.50-10.00$ & 7.50 & 8.34 & 50433 & 18389 & 68822 \\
\hline $10.00-20.00$ & 9.17 & 17.80 & 88221 & 32036 & 120257 \\
\hline $20.00-30.00$ & 0.83 & 1.99 & 100500 & 47000 & 147500 \\
\hline 30 and above & 0.83 & 3.05 & 167000 & 60000 & 227000 \\
\hline All classes & 100.00 & 100.00 & 18372 & 43195 & 61927 \\
\hline
\end{tabular}

Distribution of the rural sample households into different income groups based on the annual income is presented in Table 4. From the table 4, it is pointed out that maximum 17.5 per cent household are in the income group of Rs.50,000 - 70,000 and Rs.70,000 - 1,00,00 ( having 23.10 per cent income) i.e., average annual earnings from all the sources are Rs.60,989 and Rs.81738, respectively. The minimum 0.51 per cent household are in the income group of Rs. 25,000 - 30,000 (having 2.21 per cent income) with average income Rs.27,350/-. The non - farm-activities contributed more than agricultural and allied activities. In this group, allied activities is the main source of income from agricultural and allied activities. The contribution of non - farm- activities is more than agricultural and allied activities.

Table.4: Distribution of rural sample household by annual income

\begin{tabular}{|l|c|c|c|c|c|}
\hline Annual Household & Percentage & Percentage & \multicolumn{3}{|c|}{ Average/Household } \\
\cline { 4 - 6 } income group & $\begin{array}{c}\text { of } \\
\text { household }\end{array}$ & & $\begin{array}{c}\text { Agricultural } \\
\text { \& Allied } \\
\text { activities }\end{array}$ & $\begin{array}{c}\text { Non- } \\
\text { Agricultural } \\
\text { activities }\end{array}$ & Total \\
\hline Less than 25,000 & - & 4.50 & 4806 & 12783 & 17589 \\
\hline $25,000-30,000$ & - & 2.21 & 12767 & 14583 & 27350 \\
\hline $30,000-35,000$ & - & 3.12 & 4651 & 28447 & 33098 \\
\hline $35,000-40,000$ & 10.83 & 6.54 & 14242 & 23154 & 37396 \\
\hline $40,000-50,000$ & 15.00 & 11.14 & 15992 & 29994 & 45986 \\
\hline $50,000-70,000$ & 17.51 & 17.24 & 20522 & 40467 & 60989 \\
\hline $70,000-100,000$ & 17.51 & 23.10 & 29070 & 52668 & 81738 \\
\hline $100,000-150,000$ & 8.33 & 16.51 & 46525 & 76200 & 122725 \\
\hline $150,000-200,000$ & 0.83 & 2.10 & 4800 & 151600 & 156400 \\
\hline More than 200,000 & 3.33 & 13.54 & 21900 & 229700 & 251600 \\
\hline
\end{tabular}




\begin{tabular}{|l|c|c|c|c|c|}
\hline Annual Household & Percentage & Percentage & \multicolumn{3}{|c|}{ Average/Household } \\
\cline { 4 - 6 } income group & $\begin{array}{c}\text { of } \\
\text { of income }\end{array}$ & $\begin{array}{c}\text { Agricultural } \\
\text { \& Allied } \\
\text { household }\end{array}$ & $\begin{array}{c}\text { Non- } \\
\text { Agricultural } \\
\text { activities }\end{array}$ & Total \\
\hline All classes & 100.00 & 100.00 & 18732 & 43195 & 61927 \\
\hline
\end{tabular}

The relative per cent contributions of different sources of gross income in different categories of sample households are shown in the table 5. From the Table 5, it is observed that in the category I, 62.12 per cent income from agriculture followed livestock, non - farm - activities and salaries. In case of category II, the main source of income is non - farm -activities (29.82 per cent) followed by agricultural wages and agricultural. However, in the category III, the main source is business and craft (80.11) followed by agriculture. The remaining activities contributed nearly 9 per cent only. The IV category, salaries (71.89 per cent) is the main source of income followed by business and craft. The overall income is from agriculture followed by business and craft, non - agriculture wages and salaries.

Table.5: Percentage Composition of income under different occupational rural categories of sample households

\begin{tabular}{|l|c|c|c|c|c|}
\hline \multirow{2}{*}{ Income Sources } & \multicolumn{4}{|c|}{ Category } & \multirow{2}{*}{ Overall } \\
\cline { 2 - 5 } & $\begin{array}{c}\text { I (Farm } \\
\text { household) }\end{array}$ & $\begin{array}{c}\text { II (Wage } \\
\text { earners) }\end{array}$ & $\begin{array}{c}\text { III (Business \& } \\
\text { Craft) }\end{array}$ & $\begin{array}{c}\text { IV (Salary } \\
\text { earners) }\end{array}$ & \\
\hline Agriculture & 62.12 & 13.46 & 10.89 & 3.92 & 32.29 \\
\hline Livestock & 14.94 & 5.10 & 2.82 & 5.21 & 8.78 \\
\hline Agricultural Wages & 3.01 & 13.93 & 1.39 & 2.47 & 4.59 \\
\hline $\begin{array}{l}\text { Non Agricultural } \\
\text { Wages }\end{array}$ & 6.83 & 59.82 & 2.75 & 5.16 & 15.54 \\
\hline Business \& Craft & 5.29 & 1.99 & 80.11 & 7.14 & 22.71 \\
\hline Salaries & 6.02 & 3.11 & 1.36 & 71.89 & 14.09 \\
\hline $\begin{array}{l}\text { House-Property \& } \\
\text { money lending }\end{array}$ & 1.56 & 0.35 & 0.00 & 1.65 & 0.98 \\
\hline Pension & 0.23 & 2.24 & 0.68 & 2.56 & 1.06 \\
\hline Total & 100.00 & 100.00 & 100.00 & 100.00 & 100.00 \\
\hline
\end{tabular}

Distribution of sample household into different family size groups based on number of earners and their dependents are presented in Table 6. It is observed that highest per cent dependents (77.67 per cent) is found in household having 11 and above family size groups. The family size of $1-2$ have maximum earners (62.50 per cent). The percentage of earners in the family size groups and percentage of dependents is inversely proportionate. It indicated as earners are decreases dependents increases. The dependency ratio is increasing with increase in family size. The average dependency ratio is 2.41 .

Table.6: Percentage distribution of economic status and dependency ratio rural sample household

\begin{tabular}{|l|c|c|c|}
\hline Family size & Earners & Dependents & Dependently ratio \\
\hline $1-2$ & 62.50 & 37.50 & 0.60 \\
\hline $3-4$ & 43.20 & 56.80 & 1.31 \\
\hline $5-6$ & 32.05 & 67.95 & 2.12 \\
\hline $7-8$ & 30.33 & 69.67 & 2.97 \\
\hline $9-10$ & 28.45 & 71.55 & 2.52 \\
\hline $11 \&$ above & 22.33 & 77.67 & 3.48 \\
\hline Total & 32.25 & 77.75 & 2.41 \\
\hline
\end{tabular}


The relationship between annual household income and number of earners in different category is given in table 7 . From table 7, it is clear that among the category I (farming), single earners take lead ( 36.36 per cent) followed by 2 earners (29.55 per cent), 3 earners (20.45 per cent) and more than 3 earners (13.64 per cent). In case of category II, it is found that household having annual income up to Rs. $30,000,61.54$ per cent families have one earners followed by 2 earner earn Rs.30.000 - 50,000. Among category III (business and craft) household, maximum 6 number of household (50.00 per cent) having two earners belonging to Rs.50,000 - 100,000 followed by 3 earners (41.67 per cent) in the same income group, income up to Rs.30,000 by 1 earners. However, in case of category IV, maximum income of household (1) is more than Rs.100,000 have 3 earners followed by having two earners belonging to Rs. $50,000-100,000$ followed by 1 earners (75.00 per cent) in income up to Rs.30,000 and annual income group Rs.30,000 - 50,000.

Table.7: Distribution of households by annual income and number of earners in rural sample household

\begin{tabular}{|c|c|c|c|c|c|}
\hline Groups & $\begin{array}{l}\text { With one } \\
\text { earner }\end{array}$ & $\begin{array}{l}\text { With two } \\
\text { earner }\end{array}$ & $\begin{array}{c}\text { With three } \\
\text { earner }\end{array}$ & $\begin{array}{l}\text { With more than } \\
\text { three earner }\end{array}$ & Total \\
\hline \multicolumn{6}{|c|}{ Category - I (Farming) } \\
\hline Less than 30,000 & $8(100.00)$ & 0 & 0 & 0 & $8(100.00)$ \\
\hline $30,000-50,000$ & $6(50.00)$ & $3(25.00)$ & $2(16.67)$ & $1(8.33)$ & $12(100.00)$ \\
\hline $50,000-1,00,000$ & $1(7.14)$ & $6(42.86)$ & $7(50.00)$ & 0 & $14(100.00)$ \\
\hline $1,00,000$ and above & $1(10.00)$ & $4(40.00)$ & 0 & $5(50.00)$ & $10(100.00)$ \\
\hline Total & $16(36.36)$ & $13(29.55)$ & $9(20.45)$ & $6(13.64)$ & $44(100.00)$ \\
\hline \multicolumn{6}{|c|}{ Category - II (Wage earner) } \\
\hline Less than 30,000 & $8(61.54)$ & $2(15.38)$ & $3(23.08)$ & 0 & $13(100.00)$ \\
\hline $30,000-50,000$ & $1(20.00)$ & $3(60.00)$ & $1(60.00)$ & 0 & $5(100.00)$ \\
\hline $50,000-1,00,000$ & 0 & $2(33.33)$ & $2(33.33)$ & $2(33.33)$ & $6(100.00)$ \\
\hline $1,00,000$ and above & $1(33.33)$ & 0 & $1(33.33)$ & $1(33.33)$ & $3(100.00)$ \\
\hline Total & $10(37.04)$ & $8(29.63)$ & $6(22.22)$ & $3(11.11)$ & $27(100.00)$ \\
\hline \multicolumn{6}{|c|}{ Category - III (Business and Craft) } \\
\hline Less than 30,000 & $4(57.14)$ & $3(42.86)$ & 0 & 0 & $7(100.00)$ \\
\hline $30,000-50,000$ & $3(37.50)$ & $3(37.50)$ & $1(12.50)$ & $1(12.50)$ & $8(100.00)$ \\
\hline $50,000-1,00,000$ & 0 & $6(50.00)$ & $5(41.67)$ & $1(8.30)$ & $12(100.00)$ \\
\hline $1,00,000$ and above & $1(33.33)$ & 0 & $1(33.33)$ & $1(33.33)$ & $3(100.00)$ \\
\hline Total & $8(26.67)$ & $12(40.12)$ & $7(23.33)$ & $3(10.00)$ & $30(100.00)$ \\
\hline \multicolumn{6}{|c|}{ Category - IV (Salaries) } \\
\hline Less than 30,000 & $3(75.00)$ & $1(25.00)$ & 0 & 0 & $4(100.00)$ \\
\hline $30,000-50,000$ & $3(75.00)$ & 0 & $1(25.00)$ & 0 & $4(100.00)$ \\
\hline $50,000-1,00,000$ & $2(20.00)$ & $6(60.00)$ & $2(20.00)$ & 0 & $10(100.00)$ \\
\hline $1,00,000$ and above & 0 & 0 & $1(100.00)$ & 0 & $1(100.00)$ \\
\hline Total & $8(42.11)$ & $7(36.74)$ & $4(21.05)$ & 0 & $19(100.00)$ \\
\hline \multicolumn{6}{|c|}{ Overall } \\
\hline ess than 30,000 & $23(71.88)$ & $6(18.75)$ & $3(9.37)$ & 0 & $32(100.00)$ \\
\hline $30,000-50,000$ & $13(44.82)$ & $9(31.04)$ & $5(17.24)$ & $2(6.90)$ & $29(100.00)$ \\
\hline $50,000-1,00,000$ & $3(7.14)$ & $20(47.62)$ & $16(38.10)$ & $3(7.14)$ & $42(100.00)$ \\
\hline $1,00,000$ and above & $3(17.65)$ & $4(23.52)$ & $3(17.65)$ & $7(41.18)$ & $17(100.00)$ \\
\hline Total & $42(35.00)$ & $39(32.50)$ & $7(22.50)$ & $12(10.00)$ & $120(100.00)$ \\
\hline
\end{tabular}

From the above discussion, it is revealed that agriculture, livestock, non-farm-labor activities are the main factor for poverty assessment. Size of land holding is a crucial factor.
Marginal and small land holding couple with low income, are the main reason for poverty. The percentage of earners 
in the family size groups and percentage of dependents is inversely proportionate.

\section{REFERENCES}

[1] Adelman, Irma (May 1975) "Development Economics - A Reassessment of Goal" American Economic Reviews.

[2] Ahluwalia M.S. "Income inequality some demonisms of the problem" Redistribution with growth by $\mathrm{H}$. Chenery et-al. London, 1974.

[3] Ahluwalia, M.S. (1978) "Rural Poverty and Agricultural Performance in India" Journal of Development Studies.

[4] Ahmed, M. and Bhattacharya, N. "Size Distribution of per capita personal income in India: 1950-57, 1960-61 and 1963-64" Economic and Political Weekly, Special Number, 1972.

[5] Amaresh Bagchi : "Redistribution Role of Taxation in India: An Appraisal". In T.N. Srinivasan and P.K. Bardhan (ed.) New Delhi, 1988.

[6] Atkinson, A.B. "On the Measurement of inequalities". Journal of Economic Theory. Volume 2, September, 1970.

[7] Awasthi, O.S.(Ed.) Income, Saving and capital formation in Rural India, Indian Economic Association 1984.

[8] Bal H.S. and Gurcharan Singh "Pattern of Income Distribution in Rural areas" Indian Journal of Agricultural Economics, Vol. 35(3), 1970 pp 81-91.

[9] Bardhan P.K. and T.N. Srinivasan "Income distribution pattern, trends and policies" Economic and Political weekly, Vol. 16(17), 1971-pp 877-881.

[10] Bardhan, P.K. (1973) "On the incidence of poverty in rural India of the sixties "Economic and Political Weekly, 8 (4-6): 245-254.

[11]Bardhan, P.K. "Poverty and Trickle Down in Rural India: A Quantitative Analysis" (Eds) IN J.W. Mellor and Gunvant M. Desai. Agricultural change and rural poverty, Delhi, 1986.

[12] Basu, Shreelekha. "Pattern of Asset Holdings In indie A study at Top Asset-Holders" Economic and Political Weekly. Volume XI. Number 26, July 10, 1979

[13] Bhattacharya. 8.8. Short-Term Income Distribution. The Macmillan Co. of India Ltd, New Delhi. 1975.

[14] Bhatty, I.Z. "Inequality \& Poverty in Rural India in T.N. Srinivasan \& P K. Bardhan (ed) op. cit., pp. 291 336.

[15] Birthae, P.S. and Singh, M.K. "Structure of Rural Income Inequality A study in western Uttar Pradesh.
Indian Journal of Agricultural Economics Vol 50 (2). 1995. pp 168.175.

[16] Chakraborty. G. "Studies on size distribution of income and consumption- A Review". Margin. Volume 16. 4 Number 1. Oct. 1983.

[17] Choudhry, Uma Datta Roy. "Income, consumption and saving in urban and rural India" Review of Income and Wealth Series Vol. 14. Number 1. March 1968.

[18] Chenery. H. et.al. "Redistribution with Growth. Oxford University Press, London. 1974.

[19] Coffex, J. D. "Personal distribution of farmer's income by source and region" American Journal of Agricultural Economics. Vol. 50(5). 1968. pp, 198396

[20] Coondoo and Dipankar "A comparison of consumer expediter pattern of India middle class and working class families" Presented to $12^{\text {th }}$ Indian econometric conference. Kanpur, 1972

[21] Dacosta. E.P.W. (1971) "A portrait of Indian Poverty in Fonseca". A.J. (Ed.) Challenge of Poverty in India, Vikas, New Delhi.

[22]Dahiya, L.N. "Asset Distribution among Rural Households" Eastern Economist. February 13. 1981.

[23] Dandekar, V.M. and Rath (1971) Poverty in India (Poona, Indian School of Political Economy Ahmed, M. "Size Distribution of per capita personal income in India 1956-57". In NRS Sarthy et al (eds) Papers on National House. 1965.

[24] Dandekar, V.M. and M. Rath "Poverty in India Dimension and Trends" Economic and Political weekly, Vol. 6(1), 1971 pp 22-40

[25] Dandekar, V.M. and Rath, Neelkantha "Poverty in India, Bombay 1971."

[26] Dantwala, M.L. Poverty in India : Then and Now, New Delhi, 1973.

[27]De, B.K., Amiya, Debanath, Rajib Ghosh, Atihudhi, H.N., Debnath, A. and Ghosh, R. "Environment and Ecology, 1998". 16:1, p. 11-14.

[28] Deshpande, S.S., Mishra, A. and Mishra, M. "Profile of expenditure pattern on food and non-food items for villagers of Bhopal district in Madhya Pradesh" Indian Journals of Nutrition and Deities, 2001, 38:2, p. 45-48.

[29] Friend, Irwin and Lieberman, L. "Short-term Assets Effects on Household Saving andConsumption" The Cross-section Evidence. The American Economic Review. Vol. LXVI, Number 1, Sept. 1975.

[30] Ganguli, A. (1960) "Studies on consumer behavior", Asia Publishing House Bombay. 
[31] Ghatak, Anita: “An Aggregate Consumption Function for India 1950-51 to 1970-71. The Indian Journal of Economics. Vol. LXII, Number 245, October 1981.

[32] Government of India, Planning Commission: "Report of the Committee on Distribution of Income and Levels of Living" 1964.....Draft Fifth Five Year Plan, Vol. II, (1975-79).

[33] Govemment of India "Draft Second Five Year Plan (1956) Third Five Year Plan (1961) and Fourth Five Year Plan, Planning Commission 1969-74.

[34] Gupta, K.L. "Households savings in Financial Assets A case study of India”. The Indian Economic Journal. Vol. XVII, Numbers 4 and 5 June 1970.

[35] I.L.O. "Employment, Income and Equality" A strategy for increasing productive employment in Kenya (1972).

[36] Indira, Hirway. "Garibi Hatao: Can IRDP Do it? Economic and Political Weekly, March 30, 1985.

[37] Iyengar, N.S. and Mukherjee, M. "A Note on Derivation of size Distribution of Personal Household income from a size Distribution of Consumer Expenditure, 1957.

[38] Iyengar N.S. and Mukherjee. M. "A note on Derivation of size distribution of personnel Household income from size distribution of consumer expenditure. (1957)

[39] Kalla, Jagdeesh C. "Saving investment Behaviour of Farm-families-Udaipur district Rajasthan. Ph.D. Thesis Ohio State University, U.S.A. Vol. xxxviii, 5 (1977).

[40] Krishna, Raj "Reduction in poverty" Indian Express Chandigarh $9^{\text {th }}$ Jan., 1984 pp6.

[41] Lyudall. F.H. "The inequality of Indian incomes" Economic and Political weekly, June 1960.

[42] Mahajan, B.M. "Interracial Homogeneity of Consumer Behavior in India (Arth Vijan March 71).

[43] Minhas, B.S. (1974). Planning and the poor. S. Chand and Company Ltd., New Delhi.

[44] National Council of Applied Economic Research (1962). AllIndia Rural; Household saving survey. Vol. I, Methodology.

[45] National Council of Applied Economic Research (NCEAR) (1962), Saving survey, methodology Vol. I (New Delhi).

[46] Ojha, P.D. (1970), “A configurations of Indian Poverty: Inequality and levels of living” Reserve Bank of India Bulletin, Jan, 1970.
[47] Panikar, P.G.K. (1970) "Rural saving in India" Published by Samaiya Publication Private Limited, Bombay.

[48] Paul, Mohinder "Rich and Poor in Rural Haryana." The Tribune July 13 and July 20 (1989). NACER. (1989) Household income and its Deposition.

[49] Prema, A. and Thomas, E.K. "Distribution of farm and non-farm income among rural households". Journal of Tropical Agriculture, 1998. 36; 1-2, p. 87-88.

[50] Rai, K.N., Malkit Kaur, M.K. Chaudhary and Kusum Aggarwal. "Pattern of investment and capital formation in Haryana Agriculture" Report No.23, Department of Agricultural Economics (HAU), Hisar, 1989.

[51] Rajan V.T. and I.J. Singh "Farm income distribution and measure of income inequality"Agricultural Situation in India, Vol. 29, October, 1974 pp -554

[52] Rajaraman, Indira "Poverty, inequality and economic growth in rural Punjab, 1960-61 to 1970-71 Journal of development Studies Vol. 11(4), 1975 pp 125-137

[53] Rajendra, K., Prabhakaran, R. "Socio economic status of milk producers in a household district of Tamil Nadu. Indian Veterinary Journal 2000, 77:2, p. 157158.

[54] Rajuladevi, A.K. "Food poverty and consumption among landless labour households." Economic and Political Weekly, 2001, 36: 28, p. 2656-2664.

[55] Ranadive, K.R. "Distribution of income trends in planning." Paper presented in a seminar on income Distribution, Indian Statistical Institute, February, 1973.

[56] Randhawa, "Green Revolution- Farms and Farming" The Tribune Chandigarh, March 11 to17, 1984 p-4.

[57] Rao, N.B. "Demographic correlates of poverty in tribal households." Indian Journal of Social work, 1996, 57: 2, p. 337-355.

[58] Reddy, V.K. and Rao, N.V.M. "Levels of Living and Inequality in Andhra Pradesh." Asian Economic Review, 1995, 37: 22, pp. 352-357.

[59] Report "All India debt and investment survey RBImonthly Bulletin", 1999, 53:5 p. 673-691.

[60] Sen B. "Regional dispersion of agricultural, income implication of new technology" Economic and Political weekly, December 27, 1969

[61] Sharma, A.C., Mehta, Prakash and Singh, J.N. "Impact of Technological Development on the Pattern of income Distribution" A case study of Ludhiana District. IndianJournal of Agricultural Economic, Vol. XXVll No.4 pp. 51-55. 
[62] Sharma, R.L., Sharma, H.R. and Brij Bala "Inequality in the Distribution of Farm Assets in Himachal Pradesh, A Decomposition Analysis". Indian Journal of Agricultural Economics. Vol. 49(4), 1994.

[63] Singh, Balbir "Role of occupational factors in household consumption" IER 3 (New Sectional) 2 Oct. 1968

[64] Singh, B.K. "Composition of income and its distribution pattern on farm households". Journal of Research, Birsa Agricultural University 2001, 13:2, p. 171-175.

[65] Singh, Katar "The impact of new Agricultural Technology on Farm Income Distribution in the Aligarh district of Uttar Pradesh" Indian Journal of Agricultural Economics, Vol. 28 (2) 1973, pp 1-11

[66] Singh, RP. and Asokan, . "Concepts and methods for estimating income in villages studies in semi arid Tropical of India Economic Programme, Progress Report 28 ICRISAT, November, (1981)

[67] Susheela, H., Surendre, H.S. Padmaja, Naik, Anuradha. Joshi, Naik, P. and Joshi, A. "Prevalence of poverty in rurall households of Dharwad district" Karnataka Journal of Agricultural Science 2000, 13:1, p. 228-229.

[68] Taneja, Suresh Kumar "Saving and Investment Behavior of Rural households in Punjab. PhD. thesis (1987) pp. 102-105, K.U. Kurukshetra.

[69] Vaidyanathan, A. "Some Aspects of Inequalities in Living standard in Rural India" in TS. Srinivasan \& P.K. Bardhan (ed) op., cit. pp 215-241.

[70] Visaria Pravin (1980) "Poverty and living standards in Asia" Population and Development Review (New York), Vol. 6 No.2. 